\title{
THE CREATION OF MODERN SYSTEM OF INFORMATIONAL - ADVISORY SUPPORT AS A NECESSARY CONDITION FOR THE DEVELOPMENT OF RURAL AREAS
}

\author{
Oleksandr Chekhlatyi, Oleksandr Galych \\ Poltava State Agrarian Academy, Ukraine \\ Antonina Kalinichenko \\ Opole University, Poland
}

\begin{abstract}
This article reviews the current state of informational-advisory support of the agrarian sector of Ukrainian economy, key moments and features of the organization of advisory services in Poltava region. The basic problems and the ways of their solving, prospects and plans of advisory services in the implementation of measures to promote employment of the rural population are found out.
\end{abstract}

Keywords: informational-advisory support, advisory services, agricultural producers, rural areas

DOI: $10.17512 /$ znpcz.2016.1.08

\section{Problem statemen}

In the process of formation and development of market relations in Ukrainian agriculture newly created and reformed subjects of economic activity are faced with the global problems of the market economy, a significant need for new knowledge and expert advice. As a rule, in the developed countries in the world such assistance to private farmers informational-advisory support services provide. Long and very successful experience in the development of the agricultural sector in many European countries shows that effective activities of such services is one of the main factors of sustainable development of agricultural production, magnification of production and sales of agricultural products, improvement its quality (Калініченко 2009, p. 60; Державна цільова програма розвитку українського села на період до 2015 року)

Therefore, in Ukraine, including Poltava region, the creation and improvement of services in informational-advisory support of agro-industrial complex (AIC), for further more efficient reformation of agricultural sector of the economy, stimulation of agricultural production, positive social-economic changes in rural areas began. One of the key factors in improving the efficiency of these services is the study and implementation of the positive international experience on the functioning of information and consultation of agricultural producers, fruitful cooperation with the similar organizations abroad, and reinforced national and international financial support of advisory services in Ukraine. 


\section{Analysis of recent researches and publications}

In Ukraine, the first scientific research in the sphere of informational- advisory support began at the end of the XX century thanks to the works of O.M. Borodina, V.V. Derlemenko, R.Y. Korinets, T.P. Kalna-Dubinyuk, M.F. Kropyvka, M.I. Lobanova, P.T. Sabluk, R.M. Shmidt and others. They greatly expanded the theoretical basis of foundations of advisory and consultancy of the agricultural sector by creating conditions for identifying key aspects of the dissemination of information services in rural areas. In the works of Ukrainian scientists the essence of the counsel's activity was disclosed and the ways for improving the system of information support were proposed. First of all, determined that to achieve efficiency of advisory services required a systematic approach to the study of urgent issues and active involvement of international experience in the sphere of information and consultation support (Франчук 2010, p. 376-380).

The main purpose of the article is to study current conditions of functioning informational-advisory support system of agro-industrial complex in Ukraine, the main results of advisory services in Poltava region, their international cooperation, implementation of international experience in the advisory services, the main sources of financing and the prospects for future activities.

\section{The main research material}

Considering the fact that in different sectors of the economy development of scientific-technological progress occurred nonuniform, governments around the world have been developed special programmes of rural development, the main point of which was to ensure wide public access to innovative knowledge and information. Unfortunately in Ukraine only at the beginning of the XXI century creation an effective network of agricultural advisory structures began. Several targeted government programmes were developed and laws on development of informational-advisory support were adopted (Франчук 2010, p. 376-380).

One of the key factors in improving the efficiency of these services is the study and implementation of the positive international experience on the functioning of information and consultation of agricultural producers, fruitful cooperation with the similar organizations abroad, and reinforced national and international financial support of advisory services in Ukraine. In this regard the problem of informational consultation for ensure agriculture is seen primarily as a tool of agro-industrial complex reforming. For the rural producers it is more important to receive opportune expert information and consulting assistance at present than in the past. Rural producers need timely adjust production to changes in external factors (Франчук 2010, p. 376-380).

The tasks of created informational-advisory services is to promote the development of agricultural production and improve social-economic conditions in rural areas by creating information, consulting and training support system for business entities in agriculture and other industries, rural infrastructure and rural population. It allows spreading knowledge, providing technical assistance and other services to interested people. 
However, the main problem of the formation of effective advisory services today is the lack of sources of financing of their activities and the general financial and economic crisis that prevails in the country, total unemployment and partial employment of population.

Carrying out economic reforms in recent years in the agrarian sector of Ukraine led to the situation in rural areas in preserving social standards, employment, state of industrial relations became extremely dangerous for the existence of the village, collective and individual agricultural production. As of September 1, 2015 at employment centres of the country 1,135,6 thousand unemployed people were registered. Of the total number of unemployed - 414,8 thousand people or 36,5\% lived in rural areas (Державна служба статистики України [Електронний pecypc]. - Режим доступу: http://www.ukrstat.gov.ua).

However, in reality, the level of hidden rural unemployment is much higher than official, and some decrease in registered unemployment in the summer is a typical trend for this time of year due to seasonal and temporary employment in such kind of economic activity as agriculture. In Poltava region unemployment situation is even worse than in the whole country and is $12,8 \%$ of the economically active population of working age, compared with $10,2 \%$ on average in Ukraine. In accordance, loading the unemployed rural population (vacancy rate for one vacancy) is 18 people (Державна служба статистики України [Електронний ресурс]. - Режим доступу: http://www.ukrstat.gov.ua). Rural unemployment in Poltava region, recently quite prosperous agricultural region, now has become an acute socialeconomic problem, sharply aggravated social-labour relations in the countryside.

According to the State Statistics Committee of Ukraine, the average salary in agriculture per full-time employee in January-October 2015 amounted to 3093 UAH. It is one of the lowest salaries in comparison with salaries in other sectors of economic activity and accounts for only $76,1 \%$ of average salary in Ukraine during the same period. Salary indebtedness is also a problem. According to the State Statistics Committee of Ukraine, indebtedness on October 1, 2015 was 1906,1 million UAH (Державна служба статистики України [Електронний ресурс]. Режим доступу: http://www.ukrstat.gov.ua/).

Specific feature of the rural labour market is situation in which from nearly twenty economic activities in rural areas directly on the agricultural sector accounts for about $50 \%$ of the employed population that works by place of residence. These data indicate a small labour mobility, limited sources of income of the rural population, its slow conversion to non-agricultural activities. It follows that in the period of insufficient funding and lending, complication of economic life in the country, the welfare of rural residents increasingly depends on self-employment in a private farm and the efficiency of its activity. Therefore, in conditions of prospects of holding inefficient private farms the need for reorientation of the working rural population in other non-agricultural activities, which can be possible in rural areas, are raised (Могильний 2008). Appropriate services should facilitate it, they provide socially oriented advisory services that are necessary to the rural population and have the greatest social effect - for productive self-employment of rural population, creation of small enterprises in the sphere of social services, agricultural tourism and other non-agricultural activities. 
Their work in this direction is precisely determines and directs the Law of Ukraine "On Agricultural Advisory Activities", which in addition to determining the legal principles of agricultural advisory activity in Ukraine, aimed at improving the welfare of the rural population and development of countryside, promoting non-agricultural entrepreneurship in rural areas and employment of rural population (Закон України 2004).

It is known that in the process of formation and development of market relations in agriculture of Ukraine newly created and reformed subjects of economic activity are faced with the global problems of the market economy, informational isolation of the village a significant need for new knowledge and expert advice. As a rule, in the developed countries in the world such assistance informational-advisory support services provide to private farmers. Long and very successful experience in the development of the agricultural sector in many European countries shows that effective activities of such services is one of the main factors of sustainable development of agricultural production, magnification of production and sales of agricultural products, improvement its. quality, reduction of social tensions and improvement of social-labour relations in the countryside.

Therefore, in Ukraine, including Poltava region, the creation and improvement of services in informational-advisory support of agro-industrial complex (AIC), for further more efficient reformation of agricultural sector of the economy, stimulation of agricultural production, positive social-economic changes in rural areas began. Today the activities of advisory services should be primarily aimed to help agricultural producers in solving their problems - increasing the level of knowledge and practical skills of profitable farming entities, providing advisory services on economy, technology, management, marketing, accounting, taxes, law, ecology etc., solution of social problems in rural areas (Галич 2007).

Two agricultural advisory services, operating in Poltava region were engaged in these tasks. The first organization that provides the assistance to agricultural producers in Poltava region called OOO "Poltava Regional Agricultural Advisory Service". "Poltava Regional Agricultural Advisory Service" (PRAAS) was established in 2004 thanks to the "German-Ukrainian project of official agricultural advisory service in Poltava region" (Ukrainisch-Deutsches landwirtschaftliches Offizialberatungsprojekt Poltawa - UDOP). Teachers of Poltava State Agrarian Academy (PSAA) took active part in its creation. This advisory service operated and provided consulting services primarily thanks to financial support from the Ukrainian-German project, as well as regional budget (Калініченко 2009, p. 331-334).

Because of the expansion of demand for qualified advisory services, the need to solve the problem of the lack of effective mechanisms of cooperation of agricultural science, education and agriculture, the necessity appeared to create in Poltava region alternative to existing advisory service that would provide effective social-focused advisory services to agricultural producers and rural residents using existing technical, scientific and organizational potential of Poltava State Agrarian Academy.

This service, with the right to provide socially oriented advisory services from the State budget, was established in 2007 on the basis of Poltava State Agrarian Academy. Chairman of the Board of the newly established NGO became Vice-rector on 
scientific-pedagogical, scientific work of PSAA, PhD, associate professor O.O. Gorb. Ministry of Agrarian Policy of Ukraine on November 1, 2007 Advisory Service was listed in the Register of Agricultural Advisory Services with obtaining the certificate number 9 , which gives the right to provide socially oriented advisory services from the State budget. The organization got the name - Poltava Regional Public Organization (PRPO) "Official Agricultural Advisory Service" (Калініченко 2009, p. 331-33).

In the first year of its activity this advisory service was provided and implemented at the expense of the State budget a number of measures to provide socially oriented advisory services in the areas of Poltava region. The main focus of the service was to conduct training seminars. During the year 59 seminars were held on growing and marketing of environmentally friendly agricultural products, optimization of crop rotation, the prevention of epizootic situations, preventive sanitary and veterinary measures in case of avian influenza, rabies of all species, environmental livestock, information and advice on the productive breeds of cattle, the conditions of their detention and technologies, introduction of new technologies in livestock production and other necessary points for peasants and farmers (Калініченко 2009, p. 331-33).

PRPO "Official Agricultural Advisory Service" was quite extensive experience of international cooperation and participation in various projects, making it possible not only to learn from best practices, but also to obtain the necessary funds for a variety of educational events, providing socially oriented advisory services, such as thematic seminars, for wide range of agricultural producers and rural people. One of the results of the latest projects was the creation of "AgroEcological Centre of Poltava". For agricultural producers as a region and Ukraine as a whole, quite valuable information is posted on the website of Agro-Ecological Centre. An interesting idea is the digital library of the Centre for an effective distance studying of agricultural producers. The site contains the electronic edition of the series "Environmental Library of Poltava region", booklets on the state of environment in Poltava region, which provided analytical information on air quality, water resources, quality of drinking water, land resources, waste and recreational resources of Poltava region (Міжнародний Агро-екологічний Центр [Електронний ресурс]. - Режим доступу: http://aec.org.ua/).

For training specialists of advisory services, students in higher educational establishments by the Ministry of Agrarian Policy of Ukraine scholars of Poltava State Agrarian Academy according to special curriculum developed an electronic textbook on advisory services that includes 5 modules. This textbook was developed and became the first electronic textbook, which is approved by the Ministry of Agrarian Policy of Ukraine and offered for free sale. Teachers of the Academy, candidates of economic sciences Galych O.A. and Sosnovska O.O. according to the current needs of Agrarian Policy of Ukraine developed the study guide "Agricultural Advisory Service" approved by the Ministry of Education and Science of Ukraine.

One of the main problems for the establishment and effective operation of agricultural advisory services in Ukraine and Poltava region in particular, is to find sources of funding. In 2009, due to the financial crisis and reduction of state funding, 
the intensity of advisory services for the provision of socially oriented informationaladvisory services in rural areas has dropped significantly, but did not stop.

Order of the Ministry of Agrarian Policy of Ukraine and the Cabinet of Ministers of Ukraine 5 million UAH has allocated for the development of advisory activity in Ukraine, including 205 thousand UAH for the needs of advisory services in Poltava region. However, it was less than half the amount of money provided by the State target programme of the development of agricultural advisory activity for the period till 2009. In this situation Poltava Regional Council supported the initiative of the State Administration of allocation 100 thousand UAH for execution of regional programme of agricultural advisory service (Калініченко 2009, p. 60-68).

Following years have not been better in terms of financing of advisory activity. On the State Budget of Ukraine for the year separate line provided funds to finance state programme of agricultural advisory. However, for state support of socially oriented advisory services in 2010, as in the following years only 2 million UAH was allocated. It was only $0,035 \%$ in expenditure of Ministry of Agrarian Policy, while in 2007 the sum was 10 million UAH $(0,1538 \%)$. But even this amount was too meager for the development and establishment of advisory services in the country (Крот 2013, p. 92-96).

Local governments and local administrations, according to the social-economic development projects each year have been involving local budget funds for advisory service. But financial assistance to local administrations unfortunately cannot improve the situation with financing advisory activity for the better.

Except state target programme of agricultural advisory activity, at the list of the State programme for economic and social development of Ukraine included a number of other government programmes aimed at developing of agriculture and rural areas. In particular, this is State target programme on development of Ukrainian village until 2015. In each of these programmes there is a component which provides for social advisory services to improve the efficiency of the results of these programmes. To cover the costs, connected with providing these services, the estimate of each programme should be provided at least $5 \%$ of the total programme cost. However, the state target programme of development of Ukrainian village for the period until 2015 provided for provision of advisory service only $0,1 \%$ of the total cost of the programme, that is 96,3 million UAH (Крот 2013, p. 92-96).

So we can say that state financing of advisory services in Ukraine, including Poltava region, is extremely insufficient.

We can hope only at improvement in the future economic situation, achieving at least relative financial stability. It will revitalize advisory services for providing socially oriented advisory services and therefore give a chance to stabilize the number of employed in rural areas and even increase the number of jobs. Everything will be possible on condition of adaptation of agricultural production to the requirements of customers, both internal and external markets, changing it on environmental technologies, more deep processing of agricultural raw materials, improving the quality and safety of food.

One of the main directions for ensuring optimal employment of the economically 
active rural population should be primarily the formation of regional centres and countryside network of service, procurement and marketing cooperatives, rural service centres and other facilities for integrated development of social infrastructure. Each community must create associations of landowners and agricultural producers, which will be based on a combination of individual and group interests. It will increase productivity, will develop new agricultural enterprises and their profitable activities and will make more efficient use of human resources of the village.

\section{Conclusions}

Ukrainian producers must accelerate the growth of their competitiveness, which is impossible without a modern system of information and consultation support. At the moment it does not meet the level of international experience. Despite the fact that in recent years the number of advisory services increased, many of them were created with the direct financial support of foreign partners and programmes. Therein lies the danger. In the case of financial crisis and changes in activities of investors they will likely suspend their funding. Therefore, the branch of information and consultation support must solve the issue to ensure selfsufficiency, the ability to implement effective activities of small government grants and how can less dependent on foreign investors.

It should be noted that the activities of advisory services in Poltava region, as in Ukraine as a whole, in recent years has been primarily aimed at improving knowledge and practical skills of farming agricultural producers, rural population in a market economy. Advisory services of Poltava region made a significant contribution to the organization of agricultural producers informing, the problem of rural employment. The main area of their work was to conduct training seminars that are the best suited to the mass dissemination of knowledge among interested people, provide an opportunity to obtain the necessary information on a productive self-employment of rural population, creation of small enterprises in the sphere of social and living services, agricultural tourism and other non-agricultural activities.

\section{References}

1. Галич О.А., Сосновська О.О., Сільськогосподарське дорадництво: [Навчальний посібник]. - К.: Центр учбової літератури, 2007, p. 368.

2. Державна служба статистики Украйни [Електронний ресурс]. - Режим доступу: http://www.ukrstat.gov.ua/

3. Державна цільова програма розвитку украӥнського села на період до 2015 року: Постанова Кабінету Міністрів України [Електронний ресурс]. - Режим доступу до нормативного документа: http://www.minagro.kiev.ua.

4. Закон України "Про сільськогосподарську дорадчу діяльність"/ Відомості Верховної Ради (ВВР), 2004, - N 38, p. 470.

5. Калініченко А.В., Чехлатий О.М., Розвиток та міжнародне співробітниитво служб інформаційно-консультативного забезпечення АПК Полтавської області // Збірник наукових праць Харківського національного аграрного університету. Вісник ХНАУ. Серія "Економіка АПК і природокористування". - Харків, 2009,pp. 60-68. 
6. Калініченко А.В., Чехлатий О.М. , Костоглод К.Д., Роль інформаиійно-консультативних служб у становленні системи соціально-трудових відносин на селі // Збірник наукових праць Подільського державного аграрно-технічного університету. Випуск 17. Том 3. Кам'янець-Подільський, 2009, pp. 331-334.

7. Крот Л.М., Проблеми та перспективи фінансування дорадчої діяльності в аграрній сфері України // Інвестиції: практика та досвід. -2013. - №7, pp. 92-96.

8. Міжнародний Агро-екологічний Центр [Електронний ресурс]. - Режим доступу: http://aec.org.ua/

9. Могильний О.М. Бюджетна політика щзодо сприйняття зайнятості в сільській місиевості [Електронний ресурс]. - Режим доступу: http://www.nbuv.gov.ua/portal/Soc_Gum/Rpzn/2008-3/08momvsm-2.pdf. - Заголовок з екрану.

10. Франчук В.М. Система інформачійно-консультативного забезпечення АПК як основа нагромадження інновачійного досвіду у сфері людського капіталу //Вісник Харківського національного технічного університету сільського господарства: Економічні науки. Вип. 104. - Харків: ХНТУСГ. - 2010, pp. 376-380.

\section{TWORZENIE WSPÓŁCZESNEGO SYSTEMU WSPARCIA INFORMACYJNO-DORADCZEGO JAKO NIEZBĘDNEGO WARUNKU ROZWOJU OBSZARÓW WIEJSKICH}

Streszczenie: Artykuł ten stanowi przegląd obecnego stanu wsparcia informacyjnodoradczego dla sektora rolnego w gospodarce ukraińskiej, kluczowych momentów oraz cech organizacji usług doradczych w regionie połtawskim. Określa podstawowe problemy oraz sposoby ich rozwiązywania, perspektywy i plany usług doradczych w zakresie wdrażania środków służących promowaniu zatrudnienia wśród ludności wiejskiej.

Słowa kluczowe: wsparcie informacyjno-doradcze, usługi doradcze, producenci rolni, obszary wiejskie 